\title{
HIGHER EDUCATION TEACHING STRATEGIES: AN OVERVIEW OF ENGLISH CLASSES
}

\author{
L. Angelianawati \\ angelianawati@gmail.com \\ Universitas Kristen Indonesia
}

\begin{abstract}
ABSTRAK
Salah satu komponen utama dalam perencanaan pendidikan tinggi adalah pengajaran. Berkaitan dengan pembelajaran bahasa Inggris, pengajaran berpengaruh terhadap keberhasilan siswa di kelas bahasa Inggris. Pemilihan strategi mengajar yang tepat, yang dilakukan oleh guru bahasa Inggris, membantu pembentukan proses pembelajaran Bahasa yang efektif dan tepat sasaran. Terdapat banyak strategi mengajar yang sesuai untuk pembelajaran bahasa Inggris di pendidikan tinggi. Dalam tulisan ini akan diuraikan beberapa strategi mengajar tersebut, termasuk persyaratan dan hambatannya. Pemahaman tentang strategi mengajar terbaik yang sesuai dengan kelas bahasa Inggris sangat penting bagi guru bahasa Inggris. Ulasan dalam tulisan ini diharapkan dapat menghasilkan perbaikan dalam praktik mengajar pendidikan bahasa Inggris di perguruan tinggi.
\end{abstract}

Kata Kunci: Pendidikan Tinggi, Metode Pengajaran, Pendidikan Bahasa Inggris

\begin{abstract}
One of the main components in higher education planning is teaching. Regarding to English language learning, teaching distributes influences toward the learners' successfulness in English classes. The appropriate selection of teaching strategies conducted by the English teachers help shaping effective and on-target language learning processes. There are many teaching strategies applicable to English language learning in higher education. The present writing elaborates discussions about those teaching strategies, including its requirements and barriers. Understanding the best teaching strategies which fit the English classes is considerately important for English teachers. It is expected that the discussion will result in the betterment on English teaching practices in higher education.
\end{abstract}

Key Words: Higher Education, Teaching Strategies, English Education 


\section{INTRODUCTION}

The accelerated changes of modern world have caused impacts on Higher Education System, namely in English education. It results in a variety of challenges toward the lesson planning. English lecturers are encouraged to find appropriate teaching strategies which fit the current expectation of English classes. Therefore, explorations towards language teaching strategies are in need, covering innovations and implementations of technologies. it is acceptable since teaching quality is recently confronted by the contextual shifts within the higher-education environment, covering higher education internationalization, broad scope of education and the diversity of student profiles, technology acceleration which can make program content and pedagogies obsolete, the demand for greater civic engagement of graduates and regional development of higher education, the increased pressures of global competition, economic efficiency, and the need to produce a skilled workforce to meet the challenges of the 21st century (Hénard \& Roseveare, 2012).

In Indonesian learning context, the higher education teaching practices are expected to fulfil the requirements privileged by the government. Based on the National Standard of Higher Education regulated by the Ministry of Research, Technology and Higher
Education, number 44, year 2015. One of the fundamental standards is the learning process standard which states that learning process must partake of certain characteristics. The characteristics of the learning process should consist of interactive, holistic, integrative, scientific, contextual, thematic, effective, collaborative and student-centered nature. (Kemenristekdikti, 2015). Based on the regulation, it appears that the lecturers are expected to conduct teaching which have owned the characteristics mentioned previously in nature.

Furthermore, in accordance with the expectation of the recent higher education curriculum oriented to Kerangka Kualifikasi Nasional Indonesia (KKNI)—a statement of the Indonesian human resource quality of whose classification of qualifications is stated in the learning outcome within the curriculum, every tertiary education or higher education must have a curriculum that ensures graduates have qualifications equivalent to the qualifications agreed upon in KKNI. Therefore, every university has an obligation to facilitate its study program with all supportive elements for the successfulness of learning processes. This implies that teaching and learning processes as parts of the implementation of curriculum, namely learning processes should be well-managed, since the teaching itself should guarantee the development of 
students' attitudes, values, general knowledge, and skills (Sugiharto, 2015).

Accordingly, seen from the urgent need to conduct an excellent language learning in higher education, namely in English language learning, based of the National Standard of Higher Education, and in line with the KKNI oriented curriculum, understanding about kinds of teaching strategies applicable for higher education are in need, and should be explored further, covering its requirements and barriers. Within this writing, the explanations about those teaching strategies are provided.

\section{DISCUSSION}

Student-centered-learning in higher education

Seen from the elements of learning standardized by the Indonesian government, lecturers are expected to endeavour student-cantered-learning (SCL) atmosphere within English language learning. Studentcantered-learning can be portrayed as a learning process where the responsibility is put more on the learners' hands. In other words, it place a stronger emphasis on students. Killen (1996) suggests that in student cantered teaching approaches, teachers, in this case lecturers, remain setting the learning agenda-covering learning activities, materials, and assessment, but they have less direct control over what and how their students learn the language.
Students are urged to do decision-making, learn by doing, and perform contextualized and meaningful tasks, which are relevant to the real worlds, to the learners' real lives and experiences (Rogers, 2002).

There are ten features of student-centered-learning

proposed by Rogers (2002) in English language learning, i.e. asking don't tell, focusing on learners' experience and interests, communication over accuracy, learning by doing, learners have choices and make decisions about learning, focusing on confidence building, encouraging interests in English, open-ended tasks, high exposure to English, and learning more than language. 'Asking don't tell' refers to an activity where the lecturers expose the students to questions; the learners should bring about information, ideas, and answers, and use their language. 'Focusing on learners' experiences and interests' means that the lecturers, while selecting teaching materials, need to consider the learners personally, involving their interest areas and real-life experiences, since it makes them take part and get involved in the lesson, and later remember the lesson they have experiences. 'Communication over accuracy' means that the learning process should be focused more on the learners' ability to communicate using English. When learning a language, a learner needs to be far from the anxiousness of making mistakes; what they need 
is practicing a lot using the language beyond the grammatical mistakes. Lecturers may correct the mistakes without making interruptions within students' conversation but through feedback. 'Learning by doing' is what the students conduct and experience within their language learning. They should be actively involved within classroom activities. The next feature is that students should have choices and make decision about their own learning. Within the classroom activities, where student-centered-learning exists, students have to experience decisions making activities, for example through group work discussion where they can negotiate and make decision for a particular goal in common, or solving problems. Focusing on confidence building for real-world skills is the next feature of student-centered learning. Lecturers should provide learning atmosphere and activities where students' communicative skills can be developed. The main purpose of English language learning is that students can use the language as real and authentic as possible. Therefore, language itself will be more real and become parts of the students' lives. The following feature is encouraging students' interest in English used in the real world. In this case, what lecturers should do is selecting and/or creating materials as authentic as possible, and try to make it familiar to the students. Henceforth, the students are exposed to the English used in an interesting way, which make them learning the language at ease. Furthermore, the tasks must be open-ended rather than closeended. It means that the assessments given to students must provide opportunities for students to express ideas and knowledge freely, since there will be more than one correct answers. Lecturers can develop a variety of language skills. Alternative assessments are utilized in student-centeredlearning. High exposure to authentic materials is the subsequent feature of SCL. In English language learning students must be involved in activities where they have to have great exposure to English language referenced sources, for example through studentresearch undertaken using the internet or English references. One more important characteristic of SCL is that students learn more than language. Within the language learning, students' critical thinking and problemsolving skills must be established through creative tasks and team work or group works.

\section{Effective teaching strategies}

Teaching strategy is a skilful planning of a working system, which is dynamic and keeps on changing according to the contexts (Shafi, 2014). Teaching strategies includes all aspects of learning, i.e. teaching objectives, materials, task analysis, changes in the 
behaviour, attitude of students; their interest, capacities, abilities, and needs, etc. (idem). Accordingly, Harrell and Jordan (2004) acknowledges strategies as approaches that can be used across curricula to support the students' learning processes. They also affirm that teaching strategies are aimed at enhancing learning, by which particular underlying principles of effective English language teaching should be emphasized in each strategy. Those principles are as following: first, the instruction provided should ensure the students are given comprehensible input-students' understanding of the content; second, opportunities for increasing verbal interaction within the classroom activities are provided; third, contextualized language used is instructed as much as possible; fourth, utilizing activities which reduce students' anxiety; and fifth, the opportunities for students' active involvements in learning must be offered. Those premises are acceptable because when the students are actively engaged in learning, especially in language learning, exploring new ideas, and grasping the conceptual nature of the language, they are learning in a deeper and more meaningful way to apply that knowledge and those skills to other parts of their lives. The language learning distributes impactful experiences to the students' real worlds.

In the context of English language learning in higher education, a lecturer should be selective in deciding teaching strategies which are appropriate with the learning objectives have been set for the students to be achieved, since what is planned by the lecturer will determine and contribute to the successfulness of the students. Actually, there are no particular teaching strategies better than other teaching strategies. The fact is which teaching strategies fits or likely to be most effective to lead the students grasping the learning objectives (Killen, 1996; Killen, 2006). Every teaching strategy has its strength and weaknesses as well as requirements to be fulfilled.

There are many effective teaching strategies applicable for teaching English as a foreign language including its strengths and weaknesses, and its requirements. Killen (1996; 2006) proposes some effective language teaching strategies which can be implemented solely or in conjunction with other strategies, depending on the context. Some of the teaching strategies proposed by Killen (1996; 2006) and that of which will be explained further within this articles, involve direct instruction, discussion, smallgroup work, cooperative learning, problem solving, and student research. Furthermore, Scrivener (2005) acknowledges some toolkits as means of English language teaching.

\section{a. Direct Instruction}


The direct instruction strategy is highly teacher-directed and is among the most commonly used. This strategy is still applicable since it is effective for providing information or developing stepby-step skills. It also works well for actively involving students in knowledge construction or introducing other teaching strategies. Direct instruction may be followed by other teaching strategies such as: Lecturing, Presentation, Drill and Practice, Didactic Questions, Demonstrations, Guided and Shared - reading, listening, viewing thinking, Guest Lecture, Video, Multimedia Presentation, etc. This strategy is a bit contradictory toward the essence of SCL. However, the way how the lecturer bundles the lesson and adjoins it with other strategies, can make this strategy appropriate for teaching conceptual subject matters.

In direct instruction, teacher can follow these steps: first, begin the lesson with the statements of learning objectives; second, review the previous or prerequisite learning at the start of lesson; third, present new material with students practice after each step, fourth, give clear instructions and explanation; fifth, Provide a high level of active practice for all students; sixth, check students' understanding; seventh, provide explicit instructions for exercises, monitor and help students during the process; eighth, provide for periodic review and testing
(Rosenshine, 1987, as cited in Killen, 1996).

This strategy is the best choice for introducing students to key concepts, e.g. grammar, for teaching a skill or procedure, for preparing and making sure that the students have the basic skills or materials needed for further student-centered-learning such as problem solving, research, etc., for overcoming students' difficulties which just can be solved by a carefully constructed explanation, for simplifying the materials, for teaching materials which require explanation, modelling, questioning, and application, and when there is not enough time to carry out studentcentered activities. In direct instruction, the teacher has the authority. The teacher may present a large amount of information in a relatively short time. It is also effective in both big and small classes. It is nonthreatening environment for students since they are mostly passive and receptive. Furthermore it is a very effective way to teach factual information, concepts, and skills for lowachieving students.

When the strategy is utilized separately it may cause come problems, as follows: this strategy are dominantly engaging students in passive activities, like listening and reading, so that the students' opportunities to develop social and interpersonal skills are limited, as so as their problem solving abilities, independence, and curiosity. Somehow, the students' willingness to take 
responsibility for their learning decreases This strategy may create boredom in the classroom. The English teacher is also challenged to be confident, and skillful in creating an interesting classroom activities. (Killen, 1996; Killen, 2006)

\section{b. Discussion}

Discussion refers to face-toface interaction. Killen (1996) states that discussion is an systematic process of face-toface group interaction, where ideas are exchanged for solving problems, decision making, answering questions, as well as developing knowledge and understanding. The main concept of discussion as teaching strategy is not merely a matter of the lecturer presenting information and then asking questions toward the students; but the questions and answers must come from the students in order to help the students to learn. This strategy will lead students to the activities of thinking, expressing opinions, reasoning, making justifications. Discussion is suitable to be used when the lecturers what to develop students' critical thinking, and their skills of analysis, synthesis, and evaluation, and when the students' communication skills should be developed.

Discussion offers advantages when it is used effectively, such as: a. active learning and involvement; b. developing problem-solving skill, analytical skill, critical thinking, and communicative skill-since the students express their ideas or opinion orally; c. studentcentered-learning by constructing information and ideas; $d$. sharing knowledge, information, and ideas; e. generating new ideas; $f$. dealing with contradictory issues; g. tolerance attitude among students; and h. overcoming misconception (Killen, 1996). Besides, discussion have some limitations, i.e.: domination from talkative students, uncontrollable discussion, wasting time, reluctance for participating, misbehaved potentialities, inability to engage in the discussion due to limited vocabularies, etc. Consequently, the lecturer should prepare the classroom discussion very well. The lecturers should follow these steps to make the discussion successful: 1. Decide on the purpose of the discussion; 2. Specify the exact subject of the discussion; 3. Conduct research on background information; 4. Prepare the students to learn through discussion by ensuring that they have prior knowledge of the topics and clear understanding about the procedures and what they have to learn, and by ensuring that the issues of discussions are relevant and important to the students; 5 . Prepare the discussion plan covering objectives, subjects to be discussed, questions, and technique for closing the discussion; and 6. Prepare the discussion environment. (idem)

\section{Small group work}


Small group work can create interaction between peers or among group members. This may be an opportunity to get students to work together (Killen, 1996). This is a kind of student-selfreliant activity where the students find out solutions of the problems given in groups. The advantages of using small group work as teaching strategies are: providing a various learning tasks for different group of students in adaptation to their interest, capability, and needs, developing communication skills, enhancing students' motivation and active participation, providing nonthreatening environment, encouraging students to respect one to another and cooperate with others, making the students experience a range of social contacts, constructing understanding and activating students' prior knowledge (idem).

However, though small group work offers student-centered learning, there are some limitation that should be considered by the lecturers, namely learning environment and its procedures which must be understood by all group members, social contacts among the group members that sometimes should be accommodated, insufficient time for discussion, unlimited solutions leading to confusions, limited numbers of facilities or equipment distracting group works, opportunities to discuss irrelevant issues, difficulty to assess students individually, and students' uneasiness to direct their own learning-tendency to be teacher-reliant (idem).

The things which the lecturers need to prepare when using small group work are that the lesson plan should include learning objectives, instructions for the groups, the guideline how the groups will be formed, list-to-do for the groups, and the lesson comes into definite conclusion (idem).

\section{d. Cooperative learning}

Smaldino, Lowther, and Russell (2008) stated that "cooperative learning is a grouping strategy in which students work together to benefit each other's learning potential" (p.29). Furthermore, Johnson and Johnson (as cited in Smaldino, Lowther, and Russell, 2008) propose that in cooperative learning each member has their own role in the group, has interpersonal and leadership skills, has the ability to reflect on personal learning and group function, and is interactively engaged in the groups.

There are several approaches of cooperative learning. The approaches involve Student Teams Achievement Divisions (STAD), TeamsGames-Tournaments (TGT), Jigsaw, Group Investigation (Gl), and Dyadic. These cooperative learning approaches emphasis on team goals and team success. There are three underlying concepts of cooperative learning approaches, i.e. team rewards, 
individual accountability, and equal opportunity of success (Killen, 1996).

There are some advantages of using cooperative learning as teaching strategy. First, it provides learning benefits for all students since the group members have varying ability levels. Second, the formality of the group can be decided based on the learning requirements. Third, it opens opportunities for the students to have long-term groups. Fourth, the content areas can be varied. Fifth, it leads to students' self-reliant. Sixth, it supports cooperativeness among group members, and positive interpersonal relations with other students. Seventh, it provides a more relaxed atmosphere and non-threatening environment. Eighth, it triggers the students' decision making skill., etc. (Smaldino, Lowther, and Russell, 2008; Killen, 1996).

Conversely, cooperative learning also has some limitation. Since it is a peer teaching, the group members may have less benefits if the peer teaching is not effective. Furthermore, it takes time to make all students understand the practicalities of cooperative learning. It also needs an extended period of time to show its effectiveness to develop group interdependence. It required detailed records of students' achievements - it spends a considerable time doing this. It needs positive perceptions from the students about their abilities and contributions toward the group to make the students work cooperatively in groups. Accordingly, the number of students in one group should be kept small, to make the learning effective. Likewise, having the same level of students in one group won't enhance the learning opportunities for all members (idem).

\section{e. Problem solving}

Problem solving, sometimes called problem-based learning, may lead the students to the knowledge and skills they need in the real world. In this teaching strategy, the students are positioned in the active role of being confronted by problems situated in the real world. In this strategy the learners take responsibility of their own learning. They are positioned as someone who are facing realworld problems. There is no content presented by the lectures, but problems that results in students learning contents while solving the problems (Smaldino, Lowther, and Russell, 2008).

This strategy can develop students' analytical and logical thinking, problem-framing, problem-solving, and critical thinking skills. It also can promote students' collaborative learning skill and team work. Next, through problem-solving activities, the students engage in the real-world learning experiences, by solving authentic problems. The students knowledge and skill are optimally used while solving the problems. Additionally, the complicity of the 
issues or problems can be varied, which will enhance and increase the students capability to overcome problems. Those are some advantages of using problem-solving as teaching strategy (Smaldino, Lowther, and Russell, 2008; Killen, 1996).

The constraints of problem solving covers the selections of problems to be solved, students' confidence to solve problems, limited time to develop appropriate problems which meet the learning outcomes, encouragement toward students about the importance of the activities. Selecting appropriate problems to be solved by the students can be very demanding and difficult, since the lecturers need to consider the level of difficulty and its appropriateness toward the age of the students. Sometimes, students also feel reluctant to state their ideas, due to lack of information and knowledge. It makes the discussion doesn't run smoothly. Next, in order to create quality problems which meets the learning outcomes can be quite difficult and time consuming; therefore, the lecturer must have an ample of teaching resources as the source of ideas. In addition, mostly not all students understand the benefit of problem solving skills and how to get benefits from it, so that lecturer need to encourage students since the very beginning about its importance and the objectives (idem).

\section{f. Student-research}

In the context of language learning process, student research can be defined as a process which starts from formulating problem, collecting information, analyzing the information, and reporting the result of the analysis. It means that, when the lecturers implement student research as a teaching strategy, they engage the students in a systemic process of gathering information, interpreting the information and making conclusion based on the collected information (Killen, 1996; 2006). The goal of this strategy is to make the students be self-reliant. They should learn from the research, discover and also construct knowledge by themselves, as well as use the language appropriately.

Students research is appropriate to be used in the following circumstances:

- Students are unmotivated.

- Challenging classroom activity is needed.

- Students' understanding about other researches are required.

- Students' research skills should be developed.

- Students' appreciation toward researchers is important to be established. (Killen, 1996)

Student research will advantage the students in certain ways. First, students are actively engaged in language learning. Second, they are challenged and 
motivated to learn, discover, and explore their abilities. Third, Students may have deeper understanding and broader knowledge about the subject matter under the research, which may make them capable to understand a wide areas of study. Forth, students' critical thinking and communicative skills will be enhanced, since the students will utilize those skills within the process of the researchgathering information, discussing their works, and presenting the findings. Fifth, it students' research develops students' English language skills, since they need to read a lot of references to find grand theories from books and document; and they have to write the research reports academically and scientifically. Sixth, students' organizational and time management skills can be endeavored. Seventh, each student is shaped to be a selfreliant individual, who is responsible for his or her own learning. Seventh, students have an understanding about how to make use of data and information they have found on the field. Eighth, it encourages the students to appreciate their works.. And ninth, it can be incorporated with other teaching strategies (e.g. group work, cooperative learning, discussion or problem solving).

Beside its advantages, student-research as a teaching strategy has some limitations. It consumes a considerable amount of time to finish a research, in addition to the students' incompetence to do a research, since sometimes students are lack of skills needed to conduct research. Research is sometimes perceived to be an unenjoyable activity for some students. Moreover, just some students may have good writing skills needed to record and report the research findings. Students, those who have poor reading skill, may also get disadvantage from reading activities. Furthermore, conducting research without enough research skills can be very frustrating and demotivating students. Sometimes, students with no skills of interpreting find it difficult to interpret the information gathered. Additionally, the students' research results not always meet the lecturer's expectations. Another limitation of student research is that If the lesson is not planned well, it will become unmanageable (idem). Seen from its advantages and limitations, it appears that the implementation of student research strategy requires a wellprepared and manageable plan. The lecturers also should be ready to be the students' supervisor or facilitator.

In addition to the teaching strategies offered by Killen (1996; 2006), Scrivener (2005) acknowledges some toolkits which may be used as teaching strategies in English language learning. In other words, teaching English using media. Those toolkits includes technology and media, namely flashcards, picture 
stories, songs and music, games, movies and videos, poetry, drama, and prose (fiction and non-fiction), as well as computer assisted language learning (CALL). If the lecturers are interested to utilize teaching media, and technology based media, to aid learning, similar to other teaching strategies, the lecturer must prepare and plan the lesson carefully. All aspects of instructional strategies covering content and learning outcomes, instructional experiences, technology and media, learning environment, and people involved [students] must be taken into account. Henceforth, the utilization of the technology and media can make the language learning run effectively. The selected technology or media should be suitable with the level of the students. It must be relevant and important for the students to learn in order to achieve the learning outcomes (Smaldino, Lowther, \& Russell, 2008).

\section{The Restrictions of English Language Teaching in Higher Education}

System and the lecturer themselves somehow becomes the constraints of the teaching. Killen (2006) states "there are two forms of constraints on your teaching-those created by system and those that you [lecturer] create for yourself" (p.71). Through the system the lecturers will be restricted by time, reports, and paperwork as administration. It implies that the lecturer should put this system into their consideration while planning the learning processes. The system should not bother them in assisting the students. The next constrain is the issues of insufficient time and resources. In this case, there is no problem regarding to learning resources. The advancement of technologies, the broad access to internet, authentic materials, and realia, can become a great resources of teaching. Newspapers and magazine can be the best places to find ideas and information. Even, the university environment, students' community and parents can be used as teaching resources. Regarding to the time constraint, or insufficient time, lectures must be able to manage time well, put priorities in orderly from the most to the least sequentially.

The main resolution for overcoming all constraints of English language learning in higher education is that the lecturers are willing to be practical and creative in planning and conducting the language teaching, utilize the resources that they have optimally, implement up-to-date technologies which are familiar for the students, and expose the students to the authentic and contextualized language learning experiences. The lecturers are expected to be more imaginative, and skillful to overcome the teaching constraints they are facing, as well as be professional, 
Angelianawati, Higher Education Teaching Strategies: An Overview of English Classes

without neglecting students' needs.

\section{CONCLUSION AND SUGGESTIONS}

There are various types of English teaching strategies. However, whether the selected strategies implemented in English language learning effective or not, it depends on whether the teaching strategy is selected, planned and prepared carefully and thoroughly. There is no particular teaching strategy that is better than the others. Particular teaching strategies may be reaching its most effectivity when it is utilized separately or in conjunction with other strategies in particular contexts of language learning. In the framework of higher education, it is suggested to the lecturers to be familiar with kinds pf teaching strategies, and planned the English language learning considerately, in order to help students achieving the learning outcomes as targeted in the curriculum. Furthermore, lectures must also consider learning objectives, the students' characteristics, the available resources and the teaching materials before deciding the teaching strategy to be used.

\section{REFERENCES}

Harrell, A., \& Jordan, M. (2004).

Fifty strategies for teaching

English language learners

(2nd ed.). Upper Saddle River, New Jersey: Pearson.
Hénard, F., \& Roseveare, D.

(2012, September). Fostering quality teaching in higher education: Policies and practices. France:

Organisation for Economic Co-operation and Development (OECD). Retrieved Agustus 2018, from https://www.oecd.org/educatio n/imhe/QT\%20policies\%20an d\%20practices.pdf

Kemenristekdikti. (2015).

Permenristedikti Nomor 44

Tahun 2015 tentang Standar Nasional Pendidikan Tinggi. Jakarta, Indonesia:

Kemenristekdikti.

Killen, R. (1996). Effective teaching strategies: Lessons from research and practice. Australia: Social Science Press.

Killen, R. (2006). Effective teaching strategies: Lessons from research and practice (4th ed.). Australia: Social Science Press. Retrieved from https://books.google.co.id/boo ks?id=Y535J63QV1kC\&prints $\mathrm{e}=$ =frontcover $\# \mathrm{v}=$ onepage $\& \mathrm{q} \&$ $\mathrm{f}=\mathrm{false}$

Norland, D. L., \& Pruett-Said, T. (2006). A kaleidoscope of models and strategies for teaching English to speakers of other languages. Westport, CT: Libraries Unlimited/Teacher Ideas Press. 
Rogers, G. (2002, June). Student cantered learning: A practical guide for teachers. Bangkok, Thailand: The British Council. Retrieved from https://old.imt.liu.se/edu/Bolog na/SCL/downloadSCL\%20for\%20Thai\%20TES OL\%20paper.doc

Scrivener, J. (2005). Learning teaching: A guidebook for English language teachers (2nd ed.). UK: Macmillan ELT. Shafi, S. (2014, Mar 19). A comparative survey of teaching strategies used by P.U. and U.E. English teachers at Master's level [PowerPoint slides]. Retrieved from
https://www.slideshare.net/Sid Shafee/copm-study-ofteaching-strategies-by-puuoe-teachers

Smaldino, S.E., Lowther, D.L., \& Russell, J.D. (2008).

Instructional technology and media for learning $\left(9^{\text {th }}\right.$ ed.). Upper Saddle river, New Jersey: Pearson Education.

Sugiharto, L. (2015, November 12). Kurikulum Perguruan Tinggi (KPT) [PowerPoint slides]. Retrieved August 2018, from http://kopertis3.or.id/v2/wpcontent/uploads/KURIKULUMPENDIDIKAN-TINGGIKPT.pdf 